\title{
PROGRAM NEWS SCREEN DALAM MEMPRODUKSIKAN BERITA LOKAL DI IDX CHANNEL
}

\author{
Agnes Aprillaianah ${ }^{1}$, Febriansyah Nataly ${ }^{2}$ \\ ${ }^{1,2}$ Program Sarjana Ilmu Komunikasi \\ Sekolah Tinggi Ilmu Komunikasi Indonesia Maju \\ Jln. Harapan Nomor 50, Lenteng Agung - Jakarta Selatan 12610 \\ Telp: (021) 78894045, Email: agnesaprillia08@gmail.com, febrixxvai@ gmail.com
}

\begin{abstract}
Abstrak
Program News Screen adalah sebuah program buletin berita teraktual yang tayang di IDX Channel dengan mengangkat isu-isu ekonomi baik makro-mikro, sektoril, pasar modal dan beragam isu ekonomi lainnya khususnya isu-isu ekonomi nasional, yang dibawakan oleh salah satu presenter dengan konsep elegan, serius namun santai. Tujuan penelitian ini adalah untuk mengetahui strategi program News Screen dalam memproduksi berita lokal di IDX Channel. Metode penelitian ini menggunakan penelitian kualitatif dengan desain deskriptif dan menggunakan pendekatan observasi dimana data yang digunakan adalah data primer dari hasil pengamatan, wawancara dan studi dokumentasi dan data sekunder yang digunakan dalam tinjauan studi kepustakaan untuk mempertajam teori. Hasil penelitian dengan beberapa narasumber strategi yang dilakukan dalam produksi berita di IDX Channel berupa tujuan pembentukan program, memilih program yang bisa menarik audiens dan juga merencanakan konten atau fitur khusus untuk program yang akan dibuat, dalam perencaan program News Screen maka fitur yang akan diunggulkan adalah lebih kearah isu-isu ekonomi baik dari lokal maupun interlokal. program News Screen dalam memproduksikan berita lokal di IDX Channel terdapat beberapa tahapan meliputi perencanaan produksi berita lokal di IDX Channel yaitu materi produksi, sarana produksi, biaya produksi, organisasi pelaksana produksi dan tahap pelaksanaan. Dalam produksi program News Screen dalam memproduksikan berita lokal di IDX Channel masih banyak ditermukan kendala yang termasuk kedalam kendala segi non teknis, biasanya kendalanya seputar masalah komunikasi dan koordinasi.
\end{abstract}

Kata Kunci: Program News Screen, Berita lokal

\begin{abstract}
The News Screen program is a news program bulletin that airs on the IDX Channel by raising the economic issues of both macro-micro, sectoral, capital markets and various other economic issues, especially national economic issues, presented by one presenter with the concept of elegance, serious but relaxed. The purpose of this research is to know the News Screen program strategy in producing local news on IDX Channel. This research method uses qualitative research with descriptive design and using observation approach where data used is primary data from observation, interview and documentation study and secondary data used in library study review to sharpen theory. The results of research with some resource strategy done in news production in IDX Channel in the form of goal forming program, choose program that can attract audience and also plan content or special feature for program that will be made, in programming of News Screen program then feature to be featured is more towards economic issues both local and long-distance. The News Screen program strategy in producing local news on IDX Channel contains several stages including local news production planning on IDX Channel which are production material, production facility, production cost, production organization and implementation stage. In the production strategy of the News Screen program in producing local news on IDX Channel still many ditermukan obstacles that included into the constraints of non technical terms, usually the obstacles surrounding communication problems and coordination
\end{abstract}

Keyword: Program News Screen, Local News 


\section{Jurnal Ilmiah Komunikasi}

\section{Pendahuluan}

Menurut Effendy komunikasi adalah proses penyampaian suatu pesan oleh seseorang kepada orang lain untuk memberi tahu atau mengubah sikap, pendapat, atau perilaku, baik langsung secara lisan maupun tal langsung melalui media. ${ }^{1}$

Komunikasi merupakan suatu hal yang tidak dapat dipisahkan dalam kehidupan sehari-hari karena komunikasi dapat terjadi dalam berbagai konteks kehidupan manusia mulai dari kehidupan pribadi, pekerjaan, organisasi, kelompok, budaya, politik, ekonomi, dan lain sebagainya. Salah satu jenis komunikasi yang kita ketahui adalah komunikasi massa. Komunikasi massa adalah pesan yang dikomunikasikan melalui media massa pada sejumlah besar orang. Di era yang semakin dikuasai oleh tekhnologi dan informasi saat ini menuntut manusia untuk selalu tahu berbagai informasi. Media massa sebagai sarana informasi menjadi bagian terpenting dalam kehidupan manusia. Media massa menjadi sumber kebutuhan informasi masyarakat saat ini, melalui media massa informasi dapat disebarkan melalui berbagai bentuk diantaranya media cetak maupun elektronik, suatu program ataupun berbagai bentuk lainnya yang dikemas secara menarik dalam menyajikan berbagai informasi.

Menurut Apriadi Tamburaka

Media massa merupakan sarana penyampaian komunikasi dan informasi yang melakukan penyebaran informasi secara massal dan dapat diakses oleh masyarakat secara luas pula. Media massa mengarah pada alat atau cara yang terorganisir untuk berkomunikasi secara terbuka kepada masyarakat luas dalam jangka waktu yang ringkas. Selain itu media massa bukan hanya sekedar alat, melainkan juga institusional dalam masyarakat sehingga terjadi proses pengaturan terhadap alat itu oleh warga masyarakat melalui kekuasaan yang ada maupun melalui kesepakatan-kesepakatan lain. ${ }^{2}$

Media massa saat ini yang ikut berperan dalam menyajikan informasi kepada masyarakat luas adalah televisi. Televisi merupakan sarana yang efektif dalam menjangkau khalayak umum, televisi sangat berperan penting dalam proses komunikasi massa karena televisi merupakan media yang paling tepat dalam menyampaikan pesan yang ingin disampaikan. Sebagai teknologi modern wajar bila media televisi menjadi media massa yang efektif menjangkau khalayak-khalayak dalam waktu relatif singkat yang dapat merebut hati pemirsanya, bahkan dewasa ini televisi sudah menjadi kebutuhan yang wajib bagi setiap keluarga.

Menurut Fred Wibowo dalam bukunya yang berjudul "Teknik Produksi Program Televisi" program berita adalah program televisi yang berisi informasi, fakta, realita, sesuatu yang mempunyai nilai penting dan menarik untuk diketahui masyarakat. Karena program berita merupakan segmen program yang wajib ada di setiap stasiun televisi, sumber daya yang besar dicurahkan untuk program berita, berita selalu mengikuti perkembangan teknologi baru karena bisa mengakses suara dan gambar dari segala penjuru dunia. ${ }^{3}$

Saat ini di Indonesia sudah mengudara satu televisi pemerintah yakni TVRI, dan beberapa televisi swasta, antara lain SCTV, MNC, ANTV, Indosiar, Metro TV, Trans TV, Trans 7, TVOne, Global TV, serta televisi lokal seperti JTV, SBO, TV9, dan lain-lain. Setiap harinya stasiun televisi 


\section{Jurnal Ilmiah Komunikasi}

menyajikan berbagai jenis program acara dengan jenis yang beragam, salah satunya MNC Media.

MNC Media merupakan perusahaan media terbesar se-Asia Tenggara yang berada dalam naungan MNC Group. MNC Media mempunyai tiga stasiun televisi besar di Indonesia yaitu RCTI. Global TV dan iNews. Disamping itu, MNC Media juga mempunyai beberapa channel tersendiri yang bergerak sebagai konten channel dalam industri televisi berbayar di Indonesia yang disebut MNC Channel.

MNC Channel juga telah bekerja sama dengan Bursa Efek Indonesia membuat Channel televisi pertama menyiarkan tentang berita bisnis, keuangan dan membahas perkembangan pasar Channel tersebut bernama IDX Channel yang dibawahi oleh Inews. IDX Channel (kependekan dari Indonesia Stock Exchange Channel, sebelumnya bernama iBCM Channel (kependekan dari Indonesia Business dan Capital Market Channel) dan MNC Business) adalah sebuah stasiun televisi berita bisnis dan keuangan selama 24 jam yang menjangkau wilayah Indonesia yang membahas tentang perkembangkan pasar.

IDX Channel merupakan saluran hasil kerjasama MNC Channels dengan Bursa Efek Indonesia. Saluran ini memiliki 2 bahasa yaitu Indonesia dan Inggris. Stasiun televisi ini pertama kali siaran pada tanggal 29 September 2010 dengan nama MNC Business. Pada 10 Agustus 2015, MNC Business berganti nama menjadi iBCM Channel (Indonesia Business dan Capital Market Channel) dan sejak 18 April 2016, iBCM Channel berganti nama menjadi IDX Channel (Indonesia Stock Exchange Channel). Saluran ini hanya bisa disaksikan lewat televisi satelit oleh Indovision, Indovision Any where, MNC Play Media dan Top TV saluran 100, OkeVision saluran 99 dan First Media saluran 398.

Program News Screen menjadi program utama yang hadir menemani para penonton IDX Channel, karena program tersebut hadir pada prime time yaitu sore hari. Program News Screen adalah sebuah program buletin berita teraktual yang tayang di IDX Channel setiap pukul 17.00-17.30 setiap hari Senin sampai dengan Jumat dalam program News Screen, isu-isu yang diangkat ialah isu-isu ekonomi baik makro-mikro, sektoril, pasar modal dan beragam isu ekonomi lainnya khususnya isu-isu ekonomi nasional, yang dibawakan oleh salah satu presenter dengan konsep elegan, serius namun santai. ${ }^{4}$

Dalam industri penyiaran, strategi digunakan dalam berkompetisi dengan stasiun penyiaran lain dalam rangka memperebutkan audien. Stasiun penyiaran selalu merencanakan programnya secara strategis, yaitu merancang acara sebaik mungkin, sehingga tetap menarik dan menjaga ketertarikan pemirsanya. Salah satunya dengan cara membuat program yang dekat dengan kehidupan mereka seharihari dan sesuai dengan keinginan mereka. Departemen program dan produksi stasiun penyiaran memiliki kedudukan yang sangat strategis dalam menunjang keberhasilan stasiun penyiaran.

Program informasi adalah segala jenis siaran yang tujuannya untuk memberikan tambahan pengetahuan kepada khalayak audien. Mitchel V. Chantley menjelaskan: Berita adalah laporan yang tepat waktu mengenai fakta atau opini yang memiliki daya 


\section{Jurnal Ilmiah Komunikasi}

tarik atau hal penting atau kedua-duanya bagi masyarakat luas.

Dalam industri penyiaran, strategi digunakan dalam berkompetisi dengan stasiun penyiaran lain dalam rangka memperebutkan audien. Stasiun penyiaran selalu merencanakan programnya secara strategis, yaitu merancang acara sebaik mungkin.

Morissan dalam bukunya

"Manajemen Media Penyiaran", mengungkapkan bahwa Strategi program yang ditinjau dari dari aspek manajemen atau sering juga disebut dengan manajemen strategis (management strategic) program siaran yang terdiri dari:

1. Perencanaan Program

2. Produksi dan Pembelian Program

3. Eksekusi Program

4. Pengawasan dan Evaluasi Program.

Menurut Peter Pringle, dalam hal pengawasan program, manajer program harus melakukan hal-hal sebagai berikut: (1) mempersiapkan standar program stasiun penyiaran, (2) mengawasi seluruh isi program agar sesuai dengan standar dan aturan perundangan yang berlaku, (3) memelihara catatan program yang disiarkan, (4) mengarahkan dan mengawasi kegiatan staff departemen program, (5) memastikan kepatuhan stasiun terhadap kontrak yang sudah dibuat, (6) memastikan bahwa biaya program tidak melebihi jumlah yang sudah dianggarkan. ${ }^{5}$

Menurut Fred Wibowo ada lima cara dalam merencanakan sebuah produksi program berita televisi yaitu :

1. Materi produksi

2. Sarana produksi

3. Biaya produksi

4. Organisasi pelaksana produksi

5. Tahapan pelaksana produksi
Pada umumnya proses produksi berita televisi semua stasiun televisi sama, hanya format program berita yang berbeda-beda. Stasiun televisi lokal dituntut untuk peka dalam menyikapi akan kebutuhan tayangan program acara terhadap kebutuhan masyarakat setempat, hal ini sangat penting untuk kelangsungan hidup stasiun televisi lokal ke depan.

Keterlibatan kru bagian pemberitaan sangat mendukung proses peliputan maupun proses produksi siaran program berita. Adapun dalam proses produksi tersebut harus melalui tiga tahapan dimulai dari pra-produksi, produksi, dan pasca produksi, hal ini dilakukan untuk memudahkan dalam proses produksi,karena perencanaan sebelum produksi itu sangat penting dilakukan, dengan adanya perencanaan yang baik akan dapat menghindari kesulitankesulitan, mengurangi kesalahan dalam peliputan dilapangan, dan agar setiap kerja termanajemen secara baik sesuai dengan Standart Operational Procedure (SOP). ${ }^{6}$

\section{Metode}

Dalam penelitian ini peneliti menggunakan penelitian deskritif kualitatif karena ingin menganalisis lebih rinci tentang strategi program News Screen dalam memproduksi berita lokal di IDX Channel. Peneliti melakukan interaksi secara langsung kepada responden dengan cara wawancara dan observasi. Peneliti mecari informasi mengenai masalah terkait melalui buku, web dan atikel.

Dalam penelitian deskriptif kualitatif segala sesuatunya tidak dapat di ukur dengan angka dan teori yang digunakan dalam penelitian tidak dipaksakan untuk memperoleh gambaran seutuhnya mengenai suatu hal 


\section{Jurnal Ilmiah Komunikasi}

menurut pandangan manusia yang telah diteliti.

Metode kualitatif menjadikan peneliti sebagai instrumen utama penelitian dimana penarikan kesimpulan yang dilakukan berdasarkan hasil wawancara peneliti dengan dokumen pendukung lainnya.

Metode deskriptif hanyalah memaparkan situasi atau peristiwa. Penelitian ini tidak mencari atau menjelaskan hubungan, tidak menguji hipotesis atau membuat prediksi. Peneliti menguraikan serta mendeskripsikan bagaimana strategi dalam memproduksi berita di IDX Channel. Penelitian ini dimaksudkan untuk memberikan gambaran mengenai suatu proses yang terjadi dalam suatu obyek penelitian berdasarkan data yang diperoleh.

Sifat penelitian yang digunakan dalam penelitian ini berbentuk studi kasus. Menurut Fathoni studi kasus adalah penelitian terhadap suatu kejadian atau peristiwa. ${ }^{7}$ Kemudian pada penelitian kualitatif, terdapat obyek penelitian yang harus dipandang secara khusus, agar hasil penelitiannya mampu menggali substansi terperinci dan menyeluruh dibalik fakta. Obyek penelitian yang demikian, yang disebut sebagai 'kasus', harus dipandang sebagai satu kesatuan sistem dibatasi (bounded system) yang terikat pada tempat dan kurun waktu tertentu.

Pada penelitian ini, pengumpulan data diperoleh dari data primer dan sekunder. Data primer diperoleh melalui wawancara mendalam dengan tiga informan (producer, associate producer dan Production Assistant. Selain itu, data sekunder diperoleh melalui buku, artikel dan web untuk mendukung penelitian yang akan dibahas.
Teknik pengumpulan data yang digunakan penulis adalah dengan menggunakan metode wawancara mendalam dan observasi partisipasi (participant observer). Metode wawancara mendalam secara umum adalah proses memperoleh keterangan untuk tujuan penelitian dengan cara tanya jawab sambil bertatap muka antara pewawancara dan informan atau orang yang di wawancarai, dengan atau tanpa menggunakan pedoman (guide) wawancara.

Setelah melakukan pengumpulan data, seluruh data yang terkumpul kemudian diolah oleh peneliti. Dalam penelitian ini, analisis data dilakukan secara deskriptif kualitatif. Analisis data dilakukan dengan cara sistematis pedoman wawancara dan data kepustakaan, lalu memproses data dengan tahapan reduksi data, menyajikan data, dan kemudian menyimpulkan. Dalam mengolah data kualitatif dilakukan melalui tahap reduksi, penyajian data, dan penarikan kesimpulan. ${ }^{8}$

\section{Hasil dan Pembahasan}

IDX Channel kependekan dari Indonesian Stock Exchange Channel, sebelumnya bernama iBCM Channel (kependekan dari Indonesian Business dan Capital Market Channel) dan MNC Business) adalah sebuah stasiun televisi berita bisnis dan keuangan selama 24 jam yang menjangkau wilayah Indonesia yang membahas tentang perkembangkan pasar. IDX Channel merupakan saluran hasil kerjasama MNC Channels dengan Bursa Efek Indonesia. Saluran ini memiliki 2 bahasa yaitu Indonesia dan Inggris. IDX Channel memiliki beberapa program yang diantaranya terdapat bulletin, talkshow, laporan pasar (market report), dialogue segment, market update, 
program edukasi, dan semacamnya. ada beberapa program langsung dari IDX Channel yang disiarkan pada hari Senin sampai dengan Jumat pada jam 08.00 18.30, program yang disiarkan antara lain market sight, market now (1st session), market headlines, market now (2nd session), movers and shakers, serta News Screen.

Program News Screen adalah sebuah program buletin berita teraktual yang tayang di IDX Channel setiap pukul 17.00-17.30 setiap hari Senin sampai dengan Jumat. Konten berita yang dibahas dalam program news screen diantaranya isu-isu ekonomi baik makro-mikro, sektoril, pasar modal dan beragam isu ekonomi lainnya khususnya isu-isu ekonomi nasional.

Dalam menayangkan sebuah program acara diperlukan strategi. Strategi program berguna untuk menetapkan apa yang harus dilakukan untuk mencapai tujuan-tujuan stasiun penyiaran dengan segala kekurang dan kelebihan yang dimiliki stasiun penyiaran tersebut. Strategi program terdiri dari 4 aspek diantaranya : perencanaan program, produksi dan pembelian program, eksekusi program, pengawasan dan evaluasi program.

Dalam memproduksi suatu berita tentunya harus melalui berbagai tahap pertimbangan yang dianggap penting agar berita yang ditayangkan bisa bermanfaat dan memiliki nilai. Untuk itu seorang produser dan beberapa kru yang bertanggung jawab untuk kelancaran produksi tersebut mengupayakan kematangan persiapan. Hal yang perlu diperhatikan dalam perencanaan produksi berita lokal di IDX Chnnel adalah Materi Produksi, Sarana Produksi, Biaya Produksi, Organisasi Pelaksana Produksi, dan terakhir adalah tahapan Pelaksanaan Produksi.

Dalam produksi berita, ketelibatan kru bagian pemberitaan sangat mendukung proses peliputan maupun proses produksi siaran program berita. Dalam proses produksi berita lokal program News Screen memiliki tahapan-tahapan produksi sampai akhirnya layak ditayangkan. Konten berita yang dibahas dalam program News Screen diantaranya isu-isu ekonomi baik makro-mikro, sektoril, pasar modal dan beragam isu ekonomi lainnya khususnya isu-isu ekonomi lokal maupun interlokal.

Strategi produksi program News Screen dalam memproduksikan berita lokal di IDX Channel diantaranya strategi produksi berita lokal di IDX Channel yang terdiri dari perencanaan program, produksi dan pembelian program,eksekusi program serta pengawasan dan evaluasi program, lalu perencanaan produksi berita lokal di IDX Channel mulai dari materi produksi, sarana produksi, biaya produksi, organisasi pelaksanaan produksi, dan tahap pelaksanaan produksi. Kemudian tahapan produksi berita lokal di IDX Channel yang terbagi menjadi pra produksi, produksi, dan pasca produksi.

Strategi produksi berita lokal di IDX Channel diantaranya perencanaan program. Perencanaan program mencakup pekerjaan mempersiapkan rencana jangka pendek, menengah, dan jangka panjang yang memungkinkan stasiun penyiaran untuk mendapatkan tujuan program dan tujuan keuangannya. Perencanaan dalam strategi program diarahkan pada produksi program apa yang akan diproduksi, pemilihan program, dan penjadwalan program untuk menarik 


\section{Jurnal Ilmiah Komunikasi}

sebanyak mungkin audien yang tersedia pada waktu tertentu.

Perencaan program News Screen, maka fitur yang ingin diunggulkan adalah isu-isu ekonomi baik dari lokal maupun interlokal. Tahap selanjutnya adalah proses produksi dan pembelian program dimana pada tahap ini biasanya merumuskan program apa yang akan dijalankan serta merundingkan harga untuk pembelian program tersebut. Dalam strategi program, produksi dan pembelian program umumnya bertujuan agar program yang kita jalankan memiiki lebih banyak fitur sehingga mampu menarik audiens.

Setelah itu tahap eksekusi
program mencakup
menayangkan program sesuai dengan rencana yang sudah diterapkan. Strategi penayangan program yang baik sangat ditentukan oleh bagaimana menata atau menyusun berbagai program yang akan ditayangkan. Eksekusi program kegiatannya mencakup penayangan program yang sudah direncanakan sebelumnya, program News Screen tayang pada setiap hari senin sampai jumat pada pukul 17.00 - 17.30 dengan durasi waktu 30 menit. Terakhir yaitu pengawasan dan evaluasi program yang betujuan agar program yang dijalankan lebih terkontrol dan juga program lebih inovatif, selain itu pengawasan dan evaluasi program juga diperlukan untuk melihat sejauh mana program yang dijalankan berhasil.

Dalam memproduksi suatu berita tentunya harus melalui berbagai tahap pertimbangan yang dianggap penting agar berita yang ditayangkan bisa bermanfaat dan memiliki nilai. Untuk itu seorang produser dan beberapa kru yang bertanggung jawab untuk kelancaran produksi tersebut mengupayakan kematangan persiapan. Hal yang perlu diperhatikan dalam perencanaan produksi berita lokal di IDX Chnnel adalah Materi Produksi, Sarana Produksi, Biaya Produksi, Organisasi Pelaksana Produksi, dan terakhir adalah tahapan Pelaksanaan Produksi.

Perencanaan produksi berita lokal di IDX Channel terdiri dari materi produksi, sarana produksi, biaya produksi, organisasi pelaksanaan produksi dan tahap pelaksanaan produksi. Materi produksi berita lokal di IDX Channel meliputi berita atau isu ekonomi yang terjadi, umumnya bersifat hard news. Sarana produksi berupa peralatan penunjang agar produksi berita bisa berjalan lancar, misalnya peralatan perekam gambar, perekam suara dan sebagainya yang menjadi pendorong kelancaran seluruh persiapan produksi. Biaya produksi dalam perencanaan produksi berita lokal di IDX Channel tidak selalu sama, itu disesuaikan dengan kebutuhan produksi itu sendiri. Organisasi pelaksanaan produksi yaitu seluruh kru yang terlibat dalam suatu produksi berita, dalam perencanaan produksi berita lokal di IDX Channel umumnya sama seperti produksi berita lainnya, terdiri dari direktur pemberitaan, produser, associate producer, asisten produser, koordinator liputan, reporter, kameramen, editor, pengarah program, dan penyiar berita.

Tahap pelaksanaan produksi berita lokal di IDX Channel ketelibatan kru bagian pemberitaan sangat mendukung proses peliputan maupun proses produksi siaran program berita. Dalam proses produksi berita lokal program News Screen memiliki tahapan-tahapan produksi sampai 


\section{Jurnal Ilmiah Komunikasi}

akhirnya layak ditayangkan. Konten berita yang dibahas dalam program News Screen diantaranya isu-isu ekonomi baik makro-mikro, sektoril, pasar modal dan beragam isu ekonomi lainnya khususnya isu-isu ekonomi lokal maupun interlokal.

Tahapan produksi berita lokal di IDX Channel terbagi menjadi 3 tahapan yaitu pra produksi, produksi dan pasca produksi. Pra produksi merupakan tahap perencanaan dimana kegiatan awal yang dilakukan biasanya rapat redaksi. Rapat redaksi dihadiri oleh para produser, reporter, dan koordinator liputan, dan koordinator liputan. Rapat ini bertujuan memastikan suatu kelancaran dalam proses peliputan dan untuk membahas berbagai liputan yang telah diperoleh dan liputan lainnya yang masih harus dikejar, rapat akan memberikan keputusan peristiwa apa saja yang akan menjadi berita utama untuk hari itu, dan memilih reporter yang akan meliput dan sebagainya. Dalam rapat redaksi juga menentukan berita apa saja yang layak siar atau berita apa saja yang akan ditayangkan. Tahapan pra produksi berita lokal di IDX Channel umumnya sama seperti dengan produksi berita lainnya mulai dari rapat redaksi, penyerahan berita, membuat naskah, dubbing, dan editing, dan sampai dengan berita siap ditayangkan.

Tahapan produksi berita lokal di IDX Channel dimulai dari kerja tim liputan dalam meliput berita yakni reporter dan kameramen. Lokasi peliputan disesuaikan dengan pengamatan tentang isu apa yang sedang hangat khususnya isu tentang ekonomi, karena program News Screen konten beritanya fokus pada isu ekonomi. Setelah berita diliput lalu dibuat naskahnya oleh seorang Associate
Producer dengan melihat data data yang ada. Setelah naskah selesai lalu masuk kedalam proses editing dan dubbing. Salah satu proses penting dalam tahap produksi adalah pembuatan naskah, dalam program News Screen yang bertugas dalam pembuatan naskah yaitu seorang associate producer serta dibantu dengan asisten produser .

Tahapan terakhir yaitu pasca produksi dimana tahap ini merupakan tahap penyelesaian dan mengemas tayangan. Pasca-produksi adalah semua kegiatan setelah peliputan sampai materi itu dinyatakan selesai dan siap ditayangkan atau diputar kembali. Tahap pasca produksi berita lokal di IDX Channel yaitu diadakannya evaluasi yang bertujuan untuk melihat apakah ada kesalahan yang terjadi pada saat siaran dan kekurangan untuk dikoreksi kemudian dilaporkan kepimpinan pusat.

Kendala yang dialami dalam memproduksikan berita lokal di IDX Channel diantaranya seputar masalah peliputan serta sumber daya manusianya sendiri. Masalah peliputan yang dimaksud antara lain seperti naskah yang telat dikirim, keterbatasan gambar, pengiriman gambar reporter yang telat, gambar ngeblank dan masalah seputar peliputan lainnya. Selain itu kendala lain yang dihadapi adalah mengenai sumber daya manusianya itu sendiri yang sering terlambat sehingga berdampak pada Standar Operational Procedure (SOP) yang tidak berjalan sesuai dengan seharusnya.

\section{Kesimpulan}

Kesimpulan dari penelitian terhadap produksi berita lokal program News Screen di IDX channel, peneliti dapat menyimpulkan bahwa menurut Standart Operational Procedure (SOP) 
Jurnal Ilmiah Komunikasi

strategi program News Screen dalam memproduksikan berita lokal di IDX Channel terdapat beberapa tahapan. Tahapan tersebut meliputi perencanaan sampai dengan berita siap ditayangkan. Perencanaan produksi berita lokal di IDX Channel meliputi materi produksi, sarana produksi, biaya produksi, organisasi pelaksana produksi dan tahap pelaksanaan. Selain itu, masih banyak kendala yang ditemukan dalam produksi program News Screen di IDX Channel, kendala yang dihadapi merupakan kendala non teknis berupa komunikasi dan koordinasi tim dalam program News Screen .

\section{Saran}

Saran yang peneliti sampaikan hanya bersifat masukan yang mungkin dapat meningkatkan kualitas program News Screen yaitu lebih memperkuat strategi program News Screen dalam memproduksikan berita lokal di IDX Channel sesuai dengan Standart Operational Procedure (SOP) supaya meminimalisir terjadinya kesalahan dalam proses produksi. Selain itu, dalam memproduksikan berita lokal hendaknya setiap kendala dalam proses produksi dapat ditangani dan disikapi dengan baik, hingga berita tetap bisa disiarkan dengan baik pula. Lebih baik lagi jika kendala bisa diatasi secara bertahap dan berangsur menjadi pendukung proses produksi.

\section{Daftar Pustaka}

1. Effendi, Onong Uchjana. Dinamika Komunikasi. Bandung: Remaja Rosdakarya. 2008.

2. Tamburaka, Apriadi. Agenda Setting Media Massa. Jakarta: PT Raja Grafindo Presada. 2013.

3. Ardianto, Drs. Elvinaro, dkk. Komunikasi Massa Suatu Pengantar.
Bandung: Simbiosa Rekatama Media. 2010.

4. Bungin, Burhan. Penelitian Kualitatif (Komunikasi, Ekonomi, Kebijakan Publik, dan Ilmu Sosial Lainnya). Jakarta. Kencana Prenada Media Group. 2011.

5. Fachruddin, Andi. Dasar-Dasar Produksi Televisi (Produksi Berita, Feature, Laporan Investigasi, Dokumenter, dan Teknik Editing). Jakarta: Kencana. Prenada Media Grup. 2012.

6. Profil IDX Channel. https://id.wikipedia.org/wiki/IDX_C hannel diakses pada 10 Januari 2018.

7. Morissan. Jurnalistik Televisi Mutakhir. Tanggerang: Ramdina Prakarsa. 2010.

8. Wibowo, Fred. Teknik Produksi Program Televisi, Yogyakarta: Pinus Book Publisher. 2007.

9. Sulistyo, Basuki. Metodologi Penelitian. Jakarta: Penaku. 2010.

10. Sugiyono. Metode Penelitian Kuantitatif Kualitatif dan $R \& D$. Bandung: Alfabeta. 2012. 